\title{
sciendo
}

\section{The impact of EU's financial support on the agriculture's development: a panel data analysis}

\author{
Cristian PAUN \\ Bucharest University of Economic Studies, Bucharest, Romania \\ cristian.paun@rei.ase.ro \\ Cosmin IVASCU \\ Bucharest University of Economic Studies, Bucharest, Romania \\ cosmin_ivascu2003@yahoo.com
}

\begin{abstract}
The Common Policies represent one of the fundamental values of European Integration process. Started from coal, steel and energy, the EU common policies were significantly extended overtime. The aim of this study is to analyze the Common Agriculture Policy (CAP) from the perspective of the financing instruments for the members. The paper studies the evolution of these funds overtime, highlighting the major changes and shifts in the priorities and goals of them, their direct impact on the main sectors (including rural area) and the implication of EU enlargement on this important policy. The paper includes a cross-sector panel analysis at the level of European Union and Euro Area on the impact of the net subsidies granted to agriculture and the production volume of this sector overtime. The empirical findings confirmed a positive impact of these net subsidies on the production volume of agrosectors and the long-run relationship between the tested variables. However, the use of 3 years lags revealed a negative and statistically significant relationship between the dynamic of net subsidies and the production volume for EU and Euro area aggregated production volume dynamic. The analysis gives us the possibility to capture the main tendencies and trends and to draw important conclusions for the further developments of the EU agriculture as the subject of this common policy.
\end{abstract}

Keywords: EU, Common Agriculture Policy, EU funds, economic growth, economic development.

Please cite the article as follows: Paun, C., Ivascu, C., (2021), “The impact of EU's financial support on the agriculture's development: a panel data analysis", Management \& Marketing. Challenges for the Knowledge Society, Vol. 16, No. 2, pp. 86-100, DOI: 10.2478/mmcks-2021-0006.

\section{Introduction}

One of the most important area of the economic theory is dedicated to the theory of economic development. The economic theory is very consistent today on the drivers of wealth and economic growth.

Although, we can observe important shifts in this respect: former drivers are considered to have a lesser importance for economic growth \& development, new drivers were introduced (such as innovation or entrepreneurship) and the importance of former drivers has increased overtime (such as capital and savings) (Świadek \& Gorączkowska, 
2020; Gorączkowska, 2020). Since the beginning, the agriculture was seen as a key element for the economic development.

The Physiocrats, one of the first consistent school of economic thoughts, recognized the importance of agriculture from the perspective of its potential to provide essential resources to support a healthy and increasing population. The quality of the human capital, one of the most important production factors, is directly dependent on the development of this sector.

The later theories introduced other elements in this discussion on the economic development such as capital accumulation, entrepreneurship, innovation, natural resources etc (Kijek \& Matras-Bolibok, 2020). Despite the fact that the importance for the economic development and wealth was significantly diminished today (Miron et al., 2010), the demographic pressure still determines a reconsideration of the relevance of this sector for the wealth of a nation.

This study is analysing the development of the agriculture sector in the EU from the perspective of CAP financial instruments using a sectorial panel data analysis. The study took into consideration the long-term relationship between the dynamic of net subsidies and the dynamic of production volume for aggregated data at the level of EU countries and Euro area countries.

\section{Literature review}

Agriculture, as a sector of the material production of any national economy, has a specific complexity and a special status determined by its role in economic development, but also by the technical particularities (Dima \& Maassen, 2018) and specific economic, social, climatic limitations: (i) although agricultural production is important in the GDP formation, farmers' incomes remain still reduced compared with urban area or other industrial sectors, about $40 \%$ lower than incomes in other sectors, and farmers are forced today by many regulations to preserve the profitability of their economic activities by conserving soils, using crops or raising animal breeds with high productivity, and all this must be done in a sustainable and ecological way; (ii) unlike most other areas of activity, agriculture is still highly dependent on climatic factors and weather conditions, especially among the countries of Central and Eastern Europe (CEE) that joined the EU in the enlargements after the '90s (for instance, the GDP of Romania can be $1-1,5 \%$ affected when the climate is not favourable for the agriculture production).

Agriculture evolves in proportion to the degree of general industrialization of the EU but also to the specifics of each country, economic and social structure, relief and climate, and the role of agriculture in economic development is recognized at $\mathrm{EU}$ level and is fundamental, because being the main sector, development will be the premise and condition of economic growth (Miron et al., 2009). The direct / positive impact of the agro-sectors on the economic development became intensively studied in the economic literature (Hamulczuk, 2015, Szczepanska-Przekota, 2020; Kołodziejczak, 2020). However, Donnellan \& Hanrahan (2019) suggested that the agri-food sectors have a different impact on the income and employment at the level of EU member states. Their study was focused on the primary and processing sectors only and they recommended further empirical studies to try to explain these significant differences of this estimated impact on the economic growth.

We are currently facing, at a global level, very serious problems, and finding solutions in this regard has become a priority on which the life of the entire planet in the not too distant

Vol. 16, No. 2,pp. 86-100, ISSN 2069-8887| Management \& Marketing. Challenges for the Knowledge Society 
future could depend. Some of these problems are directly related to agriculture (sometimes irreparable degradation of the natural environment, food shortages and crises, increasing consumption of energy and raw materials, increasing population growth globally). That is why, at least at EU level, the development of agriculture has become a priority, in order to solve the problems or at least mitigate their impact on the Member States. Mavrodin (2015) pointed that "the future of the European agriculture and rural landscape is far more challenging as it used to be, as the agricultural growth will depend on the ability of increasing the productivity of the available resources or involving new resources into production without endangering the natural environment".

Thus, the term "food security" was developed, a term that appeared after the difficulties encountered more and more frequently in the supplies of agricultural raw materials worldwide, but also following the cases of food crises. However, this term of "food security" does not only refer to the quantitative consumption, but also to the provision of foods with a wide variety of assortment and with a high-quality level.

An ecological approach focusing on the links between levels, between people, their environment and factors with an impact on health and nutrition is currently being promoted, and the relationship between levels is pursued as a permanent connection between individuals with different knowledge, skills (microenvironment) and communities (Chovancová \& Tej, 2020). Governments, industry, agriculture and the economy as a whole (macro-environment) (Virglerova et al., 2020). Food security is the responsibility of every state, it is part of every state's security and global security (Kotykova \& Babych, 2019). Swinnen (2015) concluded that the CAP "increased flexibility in the implementation of the policies and the allocation of funds, and relatively minor changes in environmental and market regulations." However, the "greening" of agro-food sector is still viewed as inducing contradictory effects at the level of the EU. Environmental requirements and rules applied to the production of this sector are merely seen as barriers generating additional costs that, finally, are submitted to undermine the competitiveness and the effort to strength the EU food security (Guariso et al., 2014; Haniotis, 2015; Blanco 2018).

Rural development is also a relatively recent concept in the EU and has a short history and for quite a long time the rural area was approached only in terms of agricultural policies with the strictly defined purpose of ensuring food security or permanently increasing exports of agricultural products. However, over time, the rural area has grown in importance in EU agricultural policy, it has become one of the elements of major importance of future EU policies, even defining, which must be respected, promoted, protected (Kóródi \& Dávid, 2019). Bleahu, 2005 presents the countryside as "one of the fundamental and defining values for Europe, which must be preserved, cared for and promoted".

Therefore, current and future trends in the development of the EU in general and its agricultural policy will be to shift priorities in rural development, from supporting exports of products to maintain a positive trade balance, to policies to ensure the well-being of the population, conservation environment, sustainable development, respecting the specificity of each region or Member State. The concept of sustainable development also has a relatively short history, it was adopted at the World Conference in Rio de Janeiro in 1992. It is currently recognized as a necessary ideal by all states, but its implementation is done differently, depending on the economic power of states and their capacity for action. EU rural development policies pursue through their financial assistance programs primarily "appropriate to the perceptions of sustainable development, integrated and multi-sectorial 
to the realities of Europe" (Bleahu, 2005), adapting the granting of grants to the specific realities of each Member State.

If the beginning of the European Agricultural Policy (CAP) had the role of ensuring self-sufficiency in agro-food products and stabilizing the turmoil of the agricultural market, the CAP adapts over time to reality and problems arise in parks, crises of milk and meat overstock, etc. due to the stimulation at that time of intensive large-scale production, until the successive existences and the co-optation of new members in the EU, each newly co-opted Member State bringing new markets and advantages but also new and diversified problems. Despite the positive expected results, the impact of the CAP financing schemes and instruments still remains at least unclear at the level of European Union (Matthews, 2015).

Therefore, the CAP has been reformed several times since its implementation until now, sometimes due to problems along the way, unforeseen or not taken into account at the time of implementation, other times due to the change of priorities at EU level regarding general agricultural policies. The past shows us that the CAP will have to be constantly prepared for reform and adapt to reality and therefore must be very flexible, open to the new, anchored in the realities of the moment and ready to adapt at any time to the specific needs of each Member State. Mamatzakis \& Staikouras (2020) used panel regression and panel VAR applied on all $28 \mathrm{EU}$ member countries and they found that "results do not support the hypothesis that higher direct payments would increase agriculture income". According with their results, they proposed more supportive financial actions to boost the investments at the level of small and medium farms and a stimulus package for this sector in order to reduce the negative implications of global crisis.

Protectionism is another problem of the CAP. Despite the initial generous objectives (more incomes for the EU farmers, sustainable production growth, food security etc.), the initial instruments were much disruptive from this perspective of international trade with agricultural products (mainly primary goods). The transatlantic wars with agro-food products are well known today (Chicken War - 1963, the export subsidies war in the 1980's). Today, the trade war between EU and US is still very active and shifted to health standards (the use of chlorine, the livestock additives, the use of hormones etc.) and market regulations (place names indicating the origin of the products, bio-food regulations, eco-food regulations, environment protection etc.). The global market differences are also fueling these divergences a lot. For instance, US consumers accept biotech and EU consumers are rejecting them. The EU consumers are believing in the climate change, the US consumers are doubting this issue (Josling, 2015; Srovnalíková et al., 2020). The regulators and the politicians are always paying attention to the public perception on the key issues and they are deciding for their consumers' protection accordingly.

Climate change will certainly have a strong impact on the future of Europe's economic environment, so the "green" component of funding programs will have to be a central pillar in Member States' rural development strategies (Kelić et al., 2020). This will show the European Union's ability to permanently supply the common market with high quality agricultural products and to be competitive in the global market. European farmers will compete in a global market and must meet high standards of environment, food security, food quality, and "green" payments can be an incentive (Evteeva et al., 2019). The new funding framework allows Member States to encourage green growth through innovation, and through innovation, new, efficient and environmentally friendly technologies will be adopted over time, new products will be developed, a change that will be implemented especially in 
the context of the emerging bio-economy (Dragoi, 2017). The new pillars of the Common Agriculture Policy driving to a sustainable agriculture have been adapted to the new challenges and market shifts: (i) more economic sustainability for agro-food production and processing; (ii) more environmental sustainability including more attention paid to the pollution (air, water, land), to the use of dangerous substances that can harm the natural environment and (iii) more social sustainability referring to the rural development and reducing the living conditions gap between rural and urban areas.

The specific objectives of the CAP, according to art. 39 of the TFEU are: 1 . increasing agricultural productivity by promoting technical progress and ensuring the optimal use of factors of production (especially labour) and supporting land improvements; 2. Ensuring a fair standard of living for the agricultural population; 3. Market stabilization in order to avoid shortages or over-production; 4. Ensuring security of supply in order to improve the connectivity between the producers and their consumers; and 5. Ensuring reasonable prices for consumers by providing subsidies and direct payments to the farmers. Additionally, there are clear shifts in the reforming of the CAP, since its introduction in 1962, the most significant shifts being: the introduction of direct payments for farmers, the change of the focus from the market to the producers, higher interest for the improvement of competitiveness in this sector, more intensively use of innovation. However, we should not deny the very distortive impact of the CAP measures in the first decades (1970s, 1980s), less distortive interventions after the second CAP reform (1992), the decoupled interventions and, finally, better targeted instruments adopted by the fourth CAP reform, the most criticized one (Bureau \& Mahé, 2008; Anania \& Pupo d'Andrea, 2015; Guth et al., 2020)

Undoubtedly, the implementation of the CAP at EU level was a very necessary act and made a decisive contribution to strengthening the EU's bases as we know it today, it was a capital aid for small farmers, for less developed countries or those who entered in May. late in the common market, led to the modernization of European agriculture and paved the way for the implementation of new concepts (rural development, sustainable development, ecoconditionality, sustainable agriculture) to demand are reported today all active participants in this sector of the economy.

But, like any public policy implemented, the CAP had promoters and contestants, and each based his arguments on facts, some follow and highlight the indisputable achievements, and others highlight the shortcomings and failures of this policy from the beginning to the end. We do not intend to stand for or against the CAP, we want to highlight issues that we consider relevant to the present and future of the CAP and the EU in general. The achievements of the CAP from implementation to the present are very important for the future of agriculture as a sector of the economy, for farmers and for the entire EU population. So, the EU provides the EU with food security and stability, ensuring a constant and stable supply of high-quality food and a wide range of foods, and through CAP reforms organic farming, environmental protection, environmentally friendly working methods, and sustainable management have become increasingly important. Grants are also increasingly targeted at rural development, and rural communities are protected by the CAP, a very important achievement of this common policy, as almost $60 \%$ of the EU population lives in rural areas, which cover $90 \%$ of the Union's territory. , and farmers need help maintaining and protecting the way of life and the rural environment.

Another aspect highlighted by EU statistics: farmers represent 3\% of the total EU population and generate (together with the agro-food industry) about 6\% of EU GDP. And 
yet, they receive over $30 \%$ of the total EU budget through the CAP. In other words, according to the graph presented below, in 2019 European taxpayers granted to farmers the total subsidies of 58 billion euros. These data confirm that the decision about CAP is merely a political one, the economic arguments being marginal took into account overtime. Moreover, the direct payments granted to the farmers generated significant distortions on the production and market conditions that required other corrective measures later. From the economic point of view, the best reforms that could be applied to any economic sector should be focused not on the protection of producers or consumers through various measures but on the enhancing of the competition, strengthening the market structures, liberalizing and global openness, reducing the trade barriers and tariffs or simplifying the market regulations. Unfortunately, the reforms of the last decades are merely on the opposite direction from these economic reforming solutions. The tensions inside European Union (including BREXIT) were frequently fuelled by the collision between these two approaches (political and economic). This is also the explanation for the reduced impact of various reforms proposed and applied in the last decades (see Table 1). The "green" conditions, the "bio" requirements and the "sustainable" criteria for agriculture are suspected to add more additional costs and barriers for farmers and consumers that could enhance the chaos and market disequilibrium that already exist. The EU agriculture and the common public policy applied to it is a good example of problems derived from this replacement of the market order with the intervention disorder. The altering of prices and market structures and mechanisms is the fundamental argument for the bankruptcy of any too much "social" system.

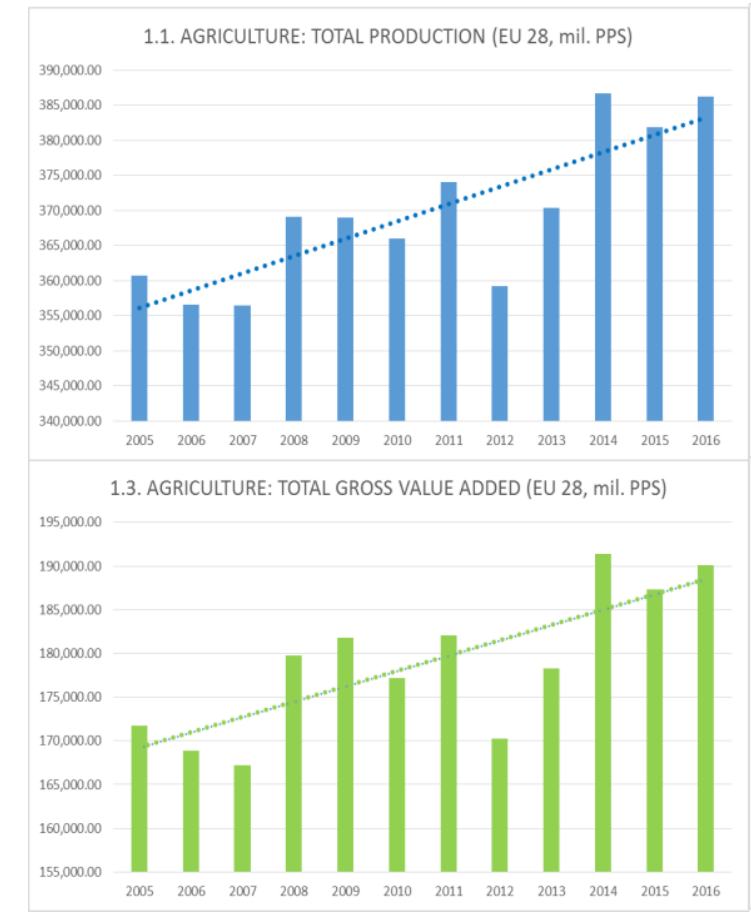

Figure 1. The effectiveness of CAP - selected macroeconomic data

Source: own estimations based on EUROSTAT DATA

To estimate the Eurostat consolidated data about the EU agriculture (Figure 1) shows the following: (i) the total production volume (crops, animals, services) significantly 
increased in the last decade (Figure 1.1.); (ii) the value of the financial support (subsidies) decreased in the same period (Figure 1.2.); (iii) the consolidated gross value added for this sector increased (Figure 1.3.); (iv) the total employment in the agriculture decreased, therefore we can appreciate that de labour productivity increased with lesser subsidies (Figure 1.4.). Additionally, the real income of the farmers slightly decreased in real terms (Figure 1.5.) and the environment protection (air pollution in this case, analysed by the level of $<10 \mu \mathrm{m}$ and $<2,5 \mu \mathrm{m}$ particulates in the air in the case of crop production) was not significantly improved these years. Based on this preliminary data analysis, we appreciate that de presence of financial support for agriculture has, at least, not a positive and clear impact on this sector.

The research objective of this study is to identify the impact of the net subsidies (the difference between subsidies received and taxes paid) received by agriculture on its development \& growth, a positive impact being presumed, at least on the short term. In order to be able to study the impact we used the panel data analysis framework. The data we used covers the period 1993 - 2016 (276 observations) and the following agro-food sectors: cereals (including seeds), industrial crops, forage plants, vegetables and horticultural products, potatoes (including seeds), fruits, wine, olive oil, other crop products, animals, animal products and agricultural services. The variables that we used for estimating the impact are: subsidies, production volume, taxes. The dependent variable is production volume (log_prod) in the selected agro-food sectors and the explanatory variable is the net subsidies received by these agro-sectors - difference between subsidies and taxes) for each sector (log_nt). The data are estimate the level of EU (not detailed by countries) and EURO area. The data are covering the $1994-2016$ and are provided by EUROSTAT. The panel is balanced (data are available for all sectors), fixed (data are available for all years) and longer than wide panel (more observed years than sectors).

The specifications of our panel regression model are the following:

$$
\begin{aligned}
& \log _{-} P r o d_{-} E U i t=a \times L_{0} g_{-} N T_{-} E U i t+c+\varepsilon i t \\
& \log _{-} P r o d_{-} E U R i t=a \times \log _{-} N T_{-} E U R i t+c+\varepsilon i t
\end{aligned}
$$

We used log data in the model in order to capture the dynamic of each variable included in the model. The descriptive statistics is presented in the Appendix 1. The Unit Root tests (data stationary problems) and cointegration tests (for long term dependence) are summarized in the Table 2 and Table 3 . The long run relationship is tested by introducing lagged values for explanatory variable. For testing this long-term relationship indicated by panel cointegration tests, we used the number of lags (years) suggested by the appropriate tests (cointegration test, AIC - Akaike's Information Criteria and BIC - Bayesian Information Criteria):

$$
\begin{aligned}
& \text { Log_Prod_EUit }=a x \text { Log_NT_EUit }-k+c+\varepsilon i t \\
& \text { Log_Prod_EURit }=a \times \log _{-} N T_{-} E U R i t-k+c+\varepsilon i t
\end{aligned}
$$


We used Eviews for data tests and panel data regressions. The Unit Root tests used are: Levin, Lin \& Chu test (2002), Im, Pesaran and Shin test (2003) and ADF - Fisher test (2001).

Table 1. Unit root tests for level

\begin{tabular}{|l|c|c|c|c|}
\hline Unit Root Tests & LOG_PROD_EU & LOG_PROD_EUR & LOG_NT_EU & LOG_NT_EUR \\
\hline Levin, Lin \& Chu t* & & & & \\
Statistic & -6.77031 & -6.20351 & -6.39608 & -7.18511 \\
Prob. & 0.0000 & 0.0000 & 0.0000 & 0.0000 \\
\hline Im, Pesaran and Shin & & & & \\
W-stat & -9.58621 & -9.1266 & -6.91611 & -7.79896 \\
Statistic & 0.0000 & 0.0000 & 0.0000 & 0.0000 \\
Prob. & & & \\
ADF - Fisher Chi- & 130.384 & 124.444 & 92.3007 & 104.668 \\
square & 0.0000 & 0.0000 & 0.0000 & 0.0000 \\
Statistic & & & & \\
Prob. & 445.4 & 574.716 & 200.578 & 222.996 \\
PP - Fisher Chi- & 0.0000 & 0.0000 & 0.0000 & 0.0000 \\
square & \multicolumn{3}{|c|}{ Source: own estimations based on EUROSTAT data } \\
Statistic & \multicolumn{4}{|c}{}
\end{tabular}

For cointegration and deterministic trend we used the following tests: Pedroni (1995, 1997, 1999; Kao 1999) and Combined Individual Test Fisher/Johansen (1999) tests.

Table 2. Cointegration tests for data panels

\begin{tabular}{|c|c|c|c|c|}
\hline \multirow{2}{*}{ Cointegration tests } & \multicolumn{2}{|c|}{ LOG_NT_EU --> LOG_PROD_EU } & \multicolumn{2}{|c|}{ LOG_NT_EUR --> LOG_PROD_EUR } \\
\hline & Statistic & Prob. & Statistic & Prob. \\
\hline Panel v-Statistic & 7.0277 & 0.0000 & 21.4020 & 0.0000 \\
\hline Panel rho-Statistic & -15.6724 & 0.0000 & -15.6392 & 0.0000 \\
\hline Panel PP-Statistic & -35.4334 & 0.0000 & -37.0076 & 0.0000 \\
\hline Panel ADF-Statistic & -11.3660 & 0.0000 & -10.7390 & 0.0000 \\
\hline $\begin{array}{ll}\text { Panel } & \text { v-Statistic } \\
\text { (weighted) } & \end{array}$ & -1.0015 & 0.8417 & -1.3192 & 0.9065 \\
\hline $\begin{array}{l}\text { Panel rho-Statistic } \\
\text { (weighted) }\end{array}$ & -10.3666 & 0.0000 & -11.1344 & 0.0000 \\
\hline $\begin{array}{l}\text { Panel PP-Statistic } \\
\text { (weighted) }\end{array}$ & -15.0409 & 0.0000 & -15.7216 & 0.0000 \\
\hline $\begin{array}{l}\text { Panel ADF-Statistic } \\
\text { (weighted) }\end{array}$ & -8.1616 & 0.0000 & -7.8642 & 0.0000 \\
\hline Kao Test (ADF) & 0.841098 & 0.2001 & 1.812088 & 0.0350 \\
\hline Fisher Test stat (none) & 173.1 & 0.0000 & 172 & 0.0000 \\
\hline Cointegration & & & & \\
\hline
\end{tabular}


Table 3. AIC / BIC tests for optimal lags selection (6 lags tested)

Panel 1 - European Union

\begin{tabular}{ccccccc}
\hline \hline Lag & LogL & LR & FPE & AIC & SC & HQ \\
\hline \hline 0 & 463.3886 & NA & $3.72 \mathrm{e}-05$ & -4.523418 & -4.490887 & -4.510258 \\
1 & 500.2695 & 72.67711 & $2.69 \mathrm{e}-05$ & -4.845780 & $-4.748188^{*}$ & $-4.806302^{*}$ \\
2 & 503.9080 & 7.098572 & $2.70 \mathrm{e}-05$ & -4.842235 & -4.679582 & -4.776439 \\
3 & 512.1362 & $\mathbf{1 5 . 8 9 1 7 0}$ & $\mathbf{2 . 5 9 e - 0 5 *}$ & $\mathbf{- 4 . 8 8 3 6 8 8 *}$ & -4.655974 & -4.791574 \\
4 & 512.8072 & 1.282760 & $2.68 \mathrm{e}-05$ & -4.851051 & -4.558275 & -4.732618 \\
5 & 516.1800 & 6.381965 & $2.70 \mathrm{e}-05$ & -4.844902 & -4.487066 & -4.700151 \\
6 & 518.0899 & 3.576422 & $2.75 \mathrm{e}-05$ & -4.824411 & -4.401513 & -4.653341 \\
\hline \hline
\end{tabular}

Akaike information criterion: -4.824411* / Schwarz criterion: -4.401513

Panel 2 - Euro area

\begin{tabular}{ccccccc}
\hline \hline Lag & LogL & LR & FPE & AIC & SC & HQ \\
\hline \hline 0 & 424.1973 & NA & $5.46 \mathrm{e}-05$ & -4.139190 & -4.106659 & -4.126030 \\
1 & 458.1933 & 66.99198 & $4.07 \mathrm{e}-05$ & -4.433267 & $-4.335676^{*}$ & $-4.393790^{*}$ \\
2 & 461.2142 & 5.893745 & $4.11 \mathrm{e}-05$ & -4.423669 & -4.261016 & -4.357873 \\
3 & 468.2777 & $\mathbf{1 3 . 6 4 2 1 7}$ & $\mathbf{3 . 9 9 e - 0 5 *}$ & $\mathbf{- 4 . 4 5 3 7 0 3}$ & -4.225988 & -4.361588 \\
4 & 470.2718 & 3.812284 & $4.07 \mathrm{e}-05$ & -4.434037 & -4.141262 & -4.315604 \\
5 & 473.4888 & 6.087159 & $4.10 \mathrm{e}-05$ & -4.426361 & -4.068525 & -4.281610 \\
6 & 475.9995 & 4.701317 & $4.16 \mathrm{e}-05$ & -4.411760 & -3.988862 & -4.240690 \\
\hline \hline
\end{tabular}

Akaike information criterion: $-4.411760 *$ / Schwarz criterion: -3.988862

Source: own estimations based on EUROSTAT data

\section{Results and discussions}

The results of the Unit Root tests summarized in the Table 2 indicate that the panel data has no presence of unit root in level (all four variables are stationary in level). The cointegration tests results presented in the Table 3 indicate that the both pairs of data series (LOG_Prod_EU / LOG_NT_EU \& LOG_PROD_EUR / LOG_NT_EUR) are cointegrated, meaning that there could be a long-run equilibrium and a common stochastic trend for both panels \& models. For determining the optimal number of lags, we used the AIC / BIC criteria. The results presented in the Table 4 indicates that the optimal lag is 3 . We run two basic models, each of them with two sub-models (see Table 5). The first basic model (see Equation 1) is taking into consideration all EU country members for agro-production in various sectors (LOG_PROD_EU) and net subsidies received by these sectors (LOG_NT_EU). The second basic models is taking into consideration only EURO country members. The sub-models are eliminating intercept (variable $\mathrm{c}$ in both models [1] and [2]) from the equation (considering that the net subsidies are the only explanatory factor for dependent variable. According with the basic models' outputs, we obtained a positive relationship between the dynamic of the net subsidies for each agro sectors and the dynamic of their production volume. The interpretation of these results is the following: the increase of net subsidies increased the 
production volume in the agriculture sector. Unfortunately, the statistical relevance (p-value, t-statistic, F-statistic for the models with intercept and Adjusted R-Squared) is very low for all the models considered in this study.

Table 4. Main results. Basic models.

\begin{tabular}{|c|c|c|c|c|}
\hline \multirow{2}{*}{ Indicators } & $\begin{array}{c}\text { Model 1 } \\
\text { NT_EU --> } \\
\text { PROD_EU }\end{array}$ & $\begin{array}{c}\text { Model 2 } \\
\text { NT_EU --> } \\
\text { PROD_EU }\end{array}$ & $\begin{array}{c}\text { Model 3 } \\
\text { NT_EUR --> } \\
\text { PROD_EUR }\end{array}$ & $\begin{array}{c}\text { Model 4 } \\
\text { NT_EUR --> } \\
\text { PROD_EUR }\end{array}$ \\
\hline NT_(coefficient) & $\mathbf{0 . 0 2 7 4 3 8}$ & $\mathbf{0 . 0 2 5 9 0 4}$ & $\mathbf{0 . 0 3 0 7 1 9}$ & $\mathbf{0 . 0 2 9 3 0 8}$ \\
t-Statistic & 1.426722 & 1.350345 & 1.427442 & 1.364159 \\
Prob & 0.1548 & 0.178 & 0.1546 & 0.1736 \\
c (coefficient) & $\mathbf{0 . 0 0 2 8 1 8}$ & na & 0.003355 & na \\
t-Statistic & 1.071409 & na & 1.063795 & na \\
\hline Prob & 0.2849 & na & 0.2884 & 0.003282 \\
Adjusted R-Sq. & 0.003751 & 0.003216 & 0.003759 & na \\
F-statistic & 2.035537 & na & 2.03759 & 3.041785 \\
Durbin Watson & & & 3.054321 & \\
stat & 3.055606 & 3.04243 & &
\end{tabular}

Source: own estimations based on EUROSTAT Data

One of the most frequent problem in the case of panel data models represents the possible random and fixed effects (cross-section and period) in the data. Therefore, in the next step, we tested their presence in both panel data. For fixed effects we used Redundant Fixed Effects - Likelihood Ratio and for random effects we used Hausman test. The results of these tests are presented in the Table 6 (Likelihood ratio fixed effects tests) and Table 7 (Hausman random effects test). According with the Hausman tests, the random effects are not present in our original estimators. According with Likelihood ratio fixed effect tests, the period fixed effects are present the original estimators must be corrected accordingly.

Table 5. Likelihood ratio fixed effects tests (all 4 basic models)

\begin{tabular}{|l|c|c|c|c|}
\hline \multirow{2}{*}{ Effects Test } & \multicolumn{2}{|l|}{ Model 1 \& 2 } & Model 3 \& 4 \\
\cline { 2 - 5 } & Statistic & Prob. & Statistic & Prob. \\
\hline Period F & 2.098 & $0.004^{*}$ & 1.792 & $0.0183^{*}$ \\
\hline Period Chi-square & 48.360 & $0.001^{*}$ & 41.816 & $0.0066^{*}$ \\
\hline Cross-Section/Period F & 1.421 & $0.072^{* *}$ & 1.211 & 0.2083 \\
\hline Cross-Section/Period Chi-square & 49.075 & $0.036^{*}$ & 42.355 & 0.1275 \\
\hline \multicolumn{5}{|c}{ Source: own estimations based on EUROSTAT Data }
\end{tabular}

Table 6. Hausman random effects test (all 4 basic models)

\begin{tabular}{|l|cc|c|}
\hline \multicolumn{1}{|c|}{ Test Summary } & Chi-Sq. Statistic & Prob. & $\begin{array}{c}\text { Random Effects } \\
\text { Method }\end{array}$ \\
\hline Model 1 \& 2 & & & \\
Cross-section random & 0.0005 & 0.9816 & Wallace - Hussain \\
Period random & 0.4136 & 0.5201 & \\
Cross-section and period random & 0.3575 & 0.5499 & \\
\hline Model 3 \& 4 & & &
\end{tabular}

Vol. 16, No. 2, pp. 86-100, ISSN 2069-8887| Management \& Marketing. Challenges for the Knowledge Society 


\begin{tabular}{|l|ll|l|} 
Cross-section random & 0.0019 & 0.9652 & \\
Period random & 0.5196 & 0.4710 & Wallace - Hussain \\
Cross-section and period random & 0.3714 & 0.5422 & \\
\hline
\end{tabular}

Source: own estimations based on EUROSTAT Data

The fitted estimators with confirmed period fixed effects are presented in Table 7.

Table 7. Fitted models with period fixed effects

\begin{tabular}{|c|c|c|c|c|}
\hline Indicators & $\begin{array}{c}\text { Model } 5 \\
\text { NT_EU --> } \\
\text { PROD_EU }\end{array}$ & $\begin{array}{c}\text { Model } 6 \\
\text { NT_EU --> } \\
\text { PROD_EU }\end{array}$ & $\begin{array}{c}\text { Model } 7 \\
\text { NT_EUR --> } \\
\text { PROD_EUR } \\
\end{array}$ & $\begin{array}{c}\text { Model } 8 \\
\text { NT_EUR --> } \\
\text { PROD_EUR } \\
\end{array}$ \\
\hline LOG_NT & $0.026^{*}$ & $0.035^{*}$ & 0.039* & $0.0252^{*}$ \\
\hline t-Statistic & 2.606 & 2.466 & 2.344 & 3.790215 \\
\hline Prob & 0.010 & 0.014 & 0.020 & 0.0002 \\
\hline c (coefficient) & 0.003* & na & $0.003^{*}$ & na \\
\hline t-Statistic & 3.458 & na & 4.855 & na \\
\hline Prob & 0.001 & na & 0.000 & na \\
\hline Adjusted R-Squared & 0.166 & 0.090 & 0.068806 & 0.085678 \\
\hline F-statistic & 2.263 & 2.188 & 1.883471 & 2.120402 \\
\hline Durbin Watson stat & 2.887 & 3.072 & 3.068526 & 2.907763 \\
\hline $\begin{array}{l}\text { Method } \\
\text { Fixed effects } \\
\text { GLS Weights } \\
\text { Coef. covar method }\end{array}$ & $\begin{array}{c}\text { EGLS } \\
\text { Period FE } \\
\text { Period } \\
\text { weights } \\
\text { Period SUR } \\
\end{array}$ & $\begin{array}{l}\text { Panel Least } \\
\text { Square } \\
\text { Period FE } \\
\text { No weights } \\
\text { Period SUR }\end{array}$ & $\begin{array}{c}\text { Panel Least Square } \\
\text { Period FE } \\
\text { No weights } \\
\text { Period SUR } \\
\end{array}$ & $\begin{array}{c}\text { EGLS } \\
\text { Period FE } \\
\text { Period weights } \\
\text { Period SUR } \\
\end{array}$ \\
\hline
\end{tabular}

Source: own estimations based on EUROSTAT Data /* - 5\% confidence level

Based on these results, we can conclude that there is a positive relationship between the dynamic of the volume of net subsidies granted to the agro-sectors and the dynamic of the production of them. This time we obtained statistical significance by fitting the outputs with the fixed effects (period fixed effects for all models). The models with intercept (Model 5 and Model 8) have higher statistical significance than the models without intercept, this indicating that other variables could have significant impact on the dynamic of production volume too. This must explore in the future by decomposing intercept in other relevant drivers for production volume dynamic (including controlling variables).

Table 8. Long-run impact of net subsidies on the production value (3 years lag)

\begin{tabular}{|l|c|c|}
\hline Indicators & Model 9 Lagged 1 & Model 10 Lagged 1 \\
NT_EU --> PROD_EU & $\mathbf{- 0 . 0 0 3 2}$ \\
\hline LOG_NT & $\mathbf{- 0 . 0 0 3 4}$ & -2.5962 \\
t-Statistic & -5.5929 & 0.0100 \\
Prob & 0.0000 & $\mathbf{0 . 0 0 3 3}$ \\
C (coefficient) & $\mathbf{0 . 0 0 2 8}$ & 5.7526 \\
t-Statistic & 5.3599 & 0.0000 \\
Prob & 0.0000 & 0.010538 \\
\hline Adjusted R-Squared & 0.013988 & 2.534863 \\
F-statistic & 3.376309 &
\end{tabular}

Vol. 16, No. 2, pp. 86-100, ISSN 2069-8887| Management \& Marketing. Challenges for the Knowledge Society 


\begin{tabular}{|l|c|c|} 
Durbin Watson stat & 2.118505 & 2.183315 \\
\hline Method & Panel EGLS & Panel EGLS \\
Fixed effects & None & None \\
GLS Weights & Cross-section SUR & Cross-section SUR \\
Coef. covar method & White cross section & White cross section \\
\hline
\end{tabular}

Source: own estimations based on EUROSTAT Data / * $5 \%$ confidence level

The cointegration tests (see Table 3) revealed the presence of a long-run effect. The AIC / BIC optimal lags selection test indicate that the optimal lags is 3 years in both data panels (see Table 4). The long-run effect results are summarized in Table 8 - 3 years lagged models (with intercept only, for both panels). The results on the long-run models (3 years lag) indicate that this possible relationship is turning into a negative and statistically significant one. This could be interpreted that the net subsidies have a short-term positive effect but that turns into a long-term negative effect.

\section{Conclusion}

The history of the CAP so far has shown that changes in this policy are difficult to accept and implement. According to EU SCAR (2015) there are voices claiming that "especially in 2020 changes will be small because the political deadline is not in sync with the budget cycle (important decisions on the CAP are not taken without an EU financial decision) and because the decision of the CAP will come at the moment when the current Commissioners hand over the mandate to their successors". Indeed, the political factor is decisive not only in the CAP, in EU politics in general and is a factor that determines whether reforms will be made in that electoral cycle or not, how and when reforms will be made and who will benefit from these reforms or new policies. Therefore, it is very important for the major players in this market, with subsequent repercussions on all participants in the common market, what political colour and what electoral agenda the EU leadership will have from one electoral cycle to another.

With all the CAP reforms from the establishment until now, one detail stands out: the labour force, especially qualified personnel, are leaving agriculture constantly. This is a serious problem, and not all the reforms so far have found solutions even for the partial reduction of the exodus of employees. However, perhaps the most important thing that will result from this type of approach is that it will prepare the European common market and the common agricultural policy for globalization, for real competition, where there are no subsidies and state aid, where only innovation and permanent development prevail, efficiency and profitability, or, in other words, this type of approach could prepare European agriculture for the capitalism in which we all live. We must mention and we have to accept a very important aspect that particularizes agriculture compared to other sectors of activity and forces us to analyse it differently from them: dependence on weather conditions, climate change and even geographical location. The EU SCAR analysis (2015) shows that agricultural research cannot afford to access, at least at present, the latest innovations and technologies, especially those used in space exploration or astronomy, technologies that have begun to be accessed more and more by most industries. For these technologies, the costs of use are still too high in agriculture, because agricultural data have a specific sensitivity to many factors, namely weather, soil type, agricultural practices used, even the geographical location of 
agricultural land, which makes it very difficult to combine data and examine the effects to obtain results relevant to the research.

The empirical findings of our study confirms a positive relationship between the dynamic of net subsidies and production volume at the level of European Union and Euro area. Although, the long-run tests indicate a potential negative impact of these net subsidies. These limitations of our study require more depth further developments: including countries instead aggregated data at the EU / Euro area level, extending the explanatory variables including controlling variables, extending the research at the regional level etc.

Therefore, a very important aspect to consider for future policies and reforms in the EU agricultural sector is to stimulate innovation and the adoption of revolutionary technologies, which are currently inaccessible to players in the common agricultural market. The agriculture of the future will certainly be very different globally, and the big players in this market are already aware that the future means globalization, innovation and technology. In order to face global competition, the EU common market and European agricultural policy will have to be completely reformed, in order to survive in a competitive global market. The future CAP will have to listen more to the voice of the farmer, to constantly adapt to his needs, to be very flexible to changes and to any external factors and, very importantly, to be able to "change the rules at any time during the game", to adapt to the realities of the moment. We must not have to wait 4 years until the next elections of the EU parliament or, more, 7 years, until the next multiannual program of the EU, for a major reform dictated by conjuncture situations or contemporary needs.

APPENDIX 1:

Descriptive statistics for the panel DATA

\begin{tabular}{|l|l|l|l|l|}
\hline Indicators & LOG_PROD_EU & LOG_PROD_EUR & LOG_NT_EU & LOG_NT_EUR \\
\hline Mean & 0.002539 & 0.003078 & -0.010182 & -0.00903 \\
\hline Median & 0.002066 & 0.002779 & -0.002098 & -0.000331 \\
\hline Maximum & 0.236363 & 0.332183 & 0.921126 & 1.110843 \\
\hline Minimum & -0.268279 & -0.275199 & -0.898789 & -0.972414 \\
\hline Std. Dev. & 0.043657 & 0.052393 & 0.136636 & 0.146536 \\
\hline Skewness & -0.09782 & 0.295154 & -0.344721 & -0.401174 \\
\hline Kurtosis & 14.92165 & 15.5291 & 24.65119 & 27.48843 \\
\hline Jarque-Bera & 1634.887 & 1809.258 & 5396.367 & 6903.759 \\
\hline Probability & 0.000000 & 0.000000 & 0.000000 & 0.000000 \\
\hline Observations & 276 & 276 & 276 & 276 \\
\hline
\end{tabular}

Source: own estimations based on EUROSTAT data

\section{References}

Anania, G., \& Pupo D’Andrea, M. R. (2015), “The 2013 Reform of the Common Agricultural Policy", in: J. Swinen, The Political Economy of the 2014-2020 Common Agricultural Policy (pp. 33-86). Brussels: Centre for European Policy Studies.

Blanco, M. (2018), "The impact of the Common Agricultural Policy on developing countries". Brussels: European Parliament, Directorate-General for External Policies. doi:10.2861/953397

Bleahu, A. (2005), "Rural development in European Union”, Calitatea vietii, XIV (3-4), 289300. 
Bureau, J.-C., \& Mahe, L.-P. (2008), “CAP reform beyond 2013: An idea for a longer view”, Paris: Notre Europe.

Chovancová, J., \& Tej, J. (2020). Decoupling economic growth from greenhouse gas emissions: the case of the energy sector in V4 countries. Equilibrium. Quarterly Journal of Economics and Economic Policy, 15(2), 235-251. https://doi.org/10.24136/eq.2020.011.

Dima, A.M., Maassen, M.A. (2018) "From waterfall to agile software: Development models in the IT sector, 2006 to 2018. impacts on company management", Journal of International Studies, 11 (2), pp. 315-326, doi: 10.14254/2071-8330.2018/11-2/21.

Donnellan, T., \& Hanrahan, K. W. (2019), Chapter 15: "Value Added and Employment Growth in EU Primary Agriculture and Food Processing", in S. M. Davidova, K. J. Thomson, \& A. K. Mishra, Rural policies and employment. Transatlantic experiences. (pp. 239-252). World Scientific Publishing Co. Pte. Ltd.

Dragoi, A.-E. (2017), "Competition Policy and the Financing of EU Agriculture”, Tools And Exemptions. Euroinfo, 1(7-8), 31-39.

Evteeva, T., Rovný, P. \& Petril'ak, M. (2019), "Farm as a form of small agricultural business in Russia: advantages and disadvantages", International Journal of Entrepreneurial Knowledge, 7(2), 53-62. doi: 10.37335/ijek.v7i2.93.

Gorączkowska, J. (2020). Enterprise innovation in technology incubators and university business incubators in the context of Polish industry. Oeconomia Copernicana, 11(4), 799-817. https://doi.org/10.24136/oc.2020.032.

Guariso, A., Squicciarini, P. M., \& Swinnen, J. (2014), "Food Price Shocks and the Political Economy of Global Agricultural and Development Policy", Applied Economic Perspectives and Policy, 36(3), 387-415. doi:10.1093/aepp/ppu020

Guth, M., Smędzik-Ambroży, K., Czyżewski, B., \& Stępień, S. (2020), “The Economic Sustainability of Farms under Common Agricultural Policy in the EU Countries", Agriculture, 10(2), 1-34. doi: https://doi.org/10.3390/agriculture 10020034

Hamulczuk, M. (2015), "Total factor productivity convergence in the EU agriculture", International Conference on Competitiveness of Agro-food and Environmental Economy Proceedings. 4, pp. 34-43. Bucharest: Bucharest University of Economic Studies.

Haniotis, T. (2015), "Achievements and Constraints of the 2013 CAP Reform”, in J. Swinen, The Political Economy of the 2014-2020 Common Agricultural Policy. An imperfect storm. Brussels: Centre for European Policy Studies.

Josling, T. (2015), "Farm Policies and World Markets: Monitoring and Disciplining the International Trade Impacts of Agricultural Policies", World Scientific Books ed., New York: World Scientific Publishing Co. Pte. Ltd. doi:https://doi.org/10.1142/9231

Kelić, I., Erceg, A. \& Čandrlić Dankoš, I. (2020), "Increasing tourism competitiveness: Connecting Blue and Green Croatia", Journal of Tourism and Services, 20(11), 132149. doi: $10.29036 /$ jots.v11i20.138.

Kijek, A., \& Matras-Bolibok, A. (2020). Technological convergence across European regions. Equilibrium. Quarterly Journal of Economics and Economic Policy, 15(2), 295-313. https://doi.org/10.24136/eq.2020.014.

Kołodziejczak, W. (2020), "Employment and Gross Value Added in Agriculture Versus Other Sectors of the European Union Economy”, Sustainability, 12(14), 1-11.

Kóródi, M., Dávid, L.D. (2019), " The uniqueness of the hungarian rural tourism supply”, Journal of Tourism and Services, 10(19), 24-39. doi: 10.29036/jots.v10i19.93.

Kotykova, 0., \& Babych, M. (2019). Limitations in availability of food in Ukraine as a result of loss and waste. Oeconomia Copernicana, 10(1), 153-172. https://doi.org/10.24136/oc.2019.008.

Mamatzakis, E., \& Staikouras, C. (2020), "Common Agriculture Police in the EU, direct payments, solvency and income", Agricultural Finance Review, 80(4), 529-547. 
Matthews, A. (2015), "Reflections on the CAP post-2014", in J. Swinen, The Political Economy of the 2014-2020 Common Agricultural Policy. An imperfect storm (pp. 493-508). Brussels: Centre for European Policy Studies.

Mavrodin, C. (2015), "The role of European funds for agriculture and rural development in Europe: a comparative perspective", International Conference on Competitiveness of Agro-food and Environmental Economy Proceedings (pp. 202-210). Bucharest: The Bucharest University of Economic Studies.

Miron, D., Dima, A.M., Vasilache, S. (2009) "Indexes of regional economic growth in postaccession Romania", Romanian Journal of Economic Forecasting, 11 (3), pp. 138-152.

Miron, D., Dima, A.M., Vasilache, S. (2010) "Modele ale influenței comerţului intra-regional asupra dezvoltarii sustenabile în România", [Models of the influence of intraregional trade on sustainable development in Romania], Amfiteatru Economic, 12 (27), pp. 27-35.

Srovnalíková, P., Semionovaitė, E., Baranskaitė, E., Labanauskaitė, D. (2020), "Evaluation of the impact of sharing economy on hotel business", Journal of Tourism and Services, 20(11), 150-169. doi: 10.29036/jots.v11i20.145.

Swinen, J. (2015), "An Imperfect Storm in the Political Economy of the Common Agricultural Policy" in J. Swinen, The Political Economy of the 2014-2020 Common Agricultural Policy. An imperfect storm (pp. 443-483). Brussels: Centre for European Policy Studies.

Szczepanska-Przekota, A. (2020), "Conditions of Agriculture Compared to Economic Growth in Selected Countries", European Research Studies Journal, 693-707.

Świadek, A., \& Gorączkowska, J. (2020). The institutional support for an innovation cooperation in industry: the case of Poland. Equilibrium. Quarterly Journal of Economics and Economic Policy, 15(4), 811-831. https://doi.org/10.24136/eq.2020.035.

Virglerova, Z., Conte, F., Amoah, J., \& Massaro, M. R. (2020), "The perception of legal risk and its impact on the business of SMEs". International Journal of Entrepreneurial Knowledge, 8(2), 1-13. doi: 10.37335/ijek.v8i2.115 